University of Nebraska - Lincoln

DigitalCommons@University of Nebraska - Lincoln

PITUITARY AND TESTICULAR RESPONSES OF BEEF BULLS TO ACTIVE IMMUNIZATION AGAINST INHIBIN ALPHA

B. D. Schanbacher USDA-ARS

Follow this and additional works at: https://digitalcommons.unl.edu/usdaarsfacpub

Part of the Agricultural Science Commons

Schanbacher, B. D., "PITUITARY AND TESTICULAR RESPONSES OF BEEF BULLS TO ACTIVE

IMMUNIZATION AGAINST INHIBIN ALPHA" (1991). Publications from USDA-ARS / UNL Faculty. 778.

https://digitalcommons.unl.edu/usdaarsfacpub/778

This Article is brought to you for free and open access by the U.S. Department of Agriculture: Agricultural Research Service, Lincoln, Nebraska at DigitalCommons@University of Nebraska - Lincoln. It has been accepted for inclusion in Publications from USDA-ARS / UNL Faculty by an authorized administrator of DigitalCommons@University of Nebraska - Lincoln. 


\title{
PITUITARY AND TESTICULAR RESPONSES OF BEEF BULLS TO ACTIVE IMMUNIZATION AGAINST INHIBIN ALPHA ${ }^{1,2}$
}

\author{
B. D. Schanbacher ${ }^{3}$ \\ U. S. Department of Agriculture ${ }^{4}$, Clay Center, NE 68933-0166 \\ ABSTRACT
}

Prepubertal crossbred beef bulls served as controls or were actively immunized against the N-terminal, 30-amino acid synthetic fragment of porcine inhibin alpha, $\mathrm{pI} \alpha(1-30)$. Antibody titers were detected in sera $\left(>40 \% \mathrm{~B} / \mathrm{B}_{\mathrm{o}}\right.$ in sera diluted 1,000 -fold) but not in rete testis fluid of 390-d-old bulls. Serum FSH and inhibin remained static during a 5-h intensive bleed; inhibin was not acutely affected by a 15 -fold LH rise and a threefold FSH rise induced by exogenous GnRH. Serum FSH, but not LH or testosterone, was consistently elevated $(P<.05)$ in immunized bulls compared with control bulls. Neither pituitary weight, pituitary gonadotropin content nor pituitary FSH/LH ratios were affected $(P>.10)$ by $\mathrm{pI} \alpha(1-30)$ active immunization. Testicular sperm density was greater $(60 \times$ $10^{6}$ vs $45 \times 10^{6}$ sperm/g testis; $P<.10$ ) in immunized bulls, but testes weight, epididymides weight and total daily sperm production remained unchanged. These results suggest that inhibin is important for regulation of FSH secretion and testicular function. Immunization with suitable inhibin vaccines may improve bull fertility.

Key Words: Bovidae, Gonadotropins, Antibodies, Rete Testis, Testes, Sperm Production

J. Anim. Sci. 1991. 69:252-257

\section{Introduction}

The effects of steroid feedback and its interaction with GnRH on gonadotropin secretion have been studied extensively; however, the relative importance of inhibin feedback remains poorly understood. The testes have been thought to secrete inhibin in response to FSH stimulation and, in turn, inhibin suppresses pituitary FSH secretion (McCullagh,

\footnotetext{
${ }^{1}$ Mention of a trade name, proprietary product or specific equipment does not constitute a guarantee or warranty of the product by the USDA and does not imply its approval to the exclusion of other products that may also be suitable.

${ }^{2}$ The author acknowledges D. J. Bolt (USDA, Beltsville, MD) for LH antiserum and J. A. Dias (NY State Dept. Health, Albany) for FSH antiserum used in this study and extends his appreciation to Shelia Schemm for laboratory technical assistance and to Linda Parnell for typing this manuscript.

${ }^{3}$ Reprint requests: Reproduction Research Unit, USDA-ARS RLH US MARC, P.O. Box 166, Clay Center, NE 68933-0166.

${ }^{4}$ ARS, Roman L. Hruska U.S. Meat Anim. Res. Center.

Received February 1, 1990

Accepted June 6, 1990.
}

1932). As a result of the recent purification, cloning and sequencing of this polypeptide (Ling et al., 1985; Miyamoto et al., 1985; Robertson et al., 1985), isolated preparations and synthetic fragments of inhibin are available for physiological studies. Follicle-stimulating hormone and inhibin concentrations were inversely related in the plasma of rams (Schanbacher, 1988a) and bulls (MacDonald et al., 1990); active immunization of ewes (Schanbacher, 1988b) and cows (Schanbacher, 1989) with an inhibin alpha fragment increased ovulation rate. Thus, the testicular response of beef bulls actively immunized against an inhibin antigen is a subject of practical interest. The objectives of this study were 1) to determine the antibody titer response of bulls actively immunized against the synthetic inhibin alpha fragment, $p I \alpha(1-30), 2)$ to monitor changes in pituitary gonadotropin content and gonadotropin secretion in immunized bulls and 3) to determine testes/epididymides weights and sperm production of immunized bulls. Secondary aims were to test for the presence of pl $\alpha(1-30)$ antibodies in rete testis fluid of immunized bulls and to assess the acute serum inhibin response to $\mathrm{GnRH}$-induced 
gonadotropin release in nonimmunized control bulls.

\section{Materials and Methods}

Animals and Treatment. Eleven crossbred bulls were assigned to one of two treatments at 2 wk of age. Five calves served as nonimmunized controls and six calves were actively immunized at 2 wk of age against the $\mathrm{N}$ terminal 30-amino acid synthetic fragment, $\mathrm{pI} \alpha(1-30)$. The primary dose was injected subcutaneously at three sites in the flank region; the injection was composed of $100 \mu \mathrm{g}$ of the antigen pIo(1-30) coupled to $100 \mu \mathrm{g}$ of human serum albumin, dissolved in saline and emulsified in Freund's complete adjuvant. Booster injections, involving antigen emulsified in Freund's incomplete adjuvant, were given at approximately 4, 8, 10, 20, 32 and 42 wk of age. Antigen preparation was identical to that reported by Schanbacher (1988a) for use in rabbits.

Bull calves remained on pasture with their dams until they were weaned at $180 \mathrm{~d}$ of age. Thereafter, the control and immunized bulls were housed in adjacent pens and fed a growing-finishing ration until they were slaughtered at approximately $390 \mathrm{~d}$ of age. Blood samples were collected by jugular venipuncture from all bulls at the time of booster immunizations and on four additional occasions during the finishing phase of the study. Additional blood samples were collected from jugular catheters at 20-min intervals for 7 $h$ from all bulls at approximately $300 \mathrm{~d}$ of age. After $300 \mathrm{~min}$ of sampling, each of the bulls was challenged intravenously with $10 \mu \mathrm{g}$ $\mathrm{GnRH}$ to elicit a synchronized release of $\mathrm{LH}$ and FSH. At slaughter, live weight, carcass weight and carcass grade and yield were recorded. Also, testes, epididymides and seminal vesicles were weighed; rete testis fluid was collected for determination of antibody titer and testis parenchyma was processed for enumeration of daily sperm production (Amann et al., 1974; Schanbacher et al., 1982). Anterior pituitaries were collected, weighed and homogenized (Keel et al., 1987; Keel and Schanbacher, 1987) so that the $30,000 \times g$ supernatant fluid could be assayed for LH and FSH content.

Inhibin Antibody Titer Assessment. Titers were determined in immunized bulls by the ability of 1,000-fold diluted sera to specifically bind ${ }^{125} \mathrm{I}$-radiolabeled pI $\alpha(1-30)$ ligand. Free and bound tracer were separated by ethanol precipitation. Specific binding was calculated as the difference between total counts bound minus background counts $(\sim 4 \%)$ divided by total counts added $(-15,000 \mathrm{cpm} ;-485 \mathrm{Ci} /$ mmol).

Radioimmunoassay of $L H, F S H$, Inhibin and Testosterone. Serum concentrations and pituitary content of LH were determined in duplicate by an established RIA for bovine LH (Schanbacher and Echternkamp, 1978). The reference preparation was NIH-LH-B10; assay sensitivity was $.5 \mathrm{ng} / \mathrm{ml}$; and the intra- and interassay $\mathrm{CV}$ were 5 and $11 \%$, respectively.

The FSH was determined in duplicate in sera and supernatant fluids of pituitary homogenates by a double antibody RIA utilizing a rabbit antiovine FSH (JAD 17-679; Krystek et al., 1985) and 125I-radiolabeled oFSH (LER-1976-A2). The FSH was radioiodinated by the chloramine $T$ reaction, purified on Bio-Gel $\mathrm{P}-100$ and Dowex anion-exchange chromatography and used at $\sim 15,000 \mathrm{cpm}(-380 \mathrm{Ci} / \mathrm{mmol})$ per tube. Preprecipitated sheep anti-rabbit gamma globulin complex was used to hasten the assay (Schanbacher, 1988a). The reference preparation was USDA-FSH-B1; assay sensitivity was $5 \mathrm{ng} / \mathrm{ml}$; the intra- and interassay $\mathrm{CV}$ were 7 and $9 \%$, respectively.

Inhibin concentrations were determined in duplicate in sera of control bulls by a RIA described previously (Schanbacher, 1988a). Values are expressed in femtomole equivalents of the reference preparation, $\mathrm{pI} \alpha(1-30)$. Assay sensitivity was $10 \mathrm{fmol} / \mathrm{ml}$ sera and the mean intra-assay $\mathrm{CV}$ was $6 \%$.

Testosterone concentrations were determined in duplicate by direct RIA (Schanbacher and D'Occhio, 1982). Assay sensitivity was .1 $\mathrm{ng} / \mathrm{ml}$ and the mean intra-assay CV was $7 \%$.

Statistical Analysis. Differences in treatment means between control and immunized bulls were assessed by the Students' $t$-test, and treatment differences in secretory patterns of hormones during the 7 -h intensive bleed were assessed by a repeated measures ANOVA (SAS, 1985).

\section{Results}

Antibody Titer. Nonimmunized bull calves did not exhibit pI $\alpha(1-30)$ antibodies $(\leq 2.5 \%)$, whereas those immunized against the $\operatorname{pI} \alpha(1-$ 


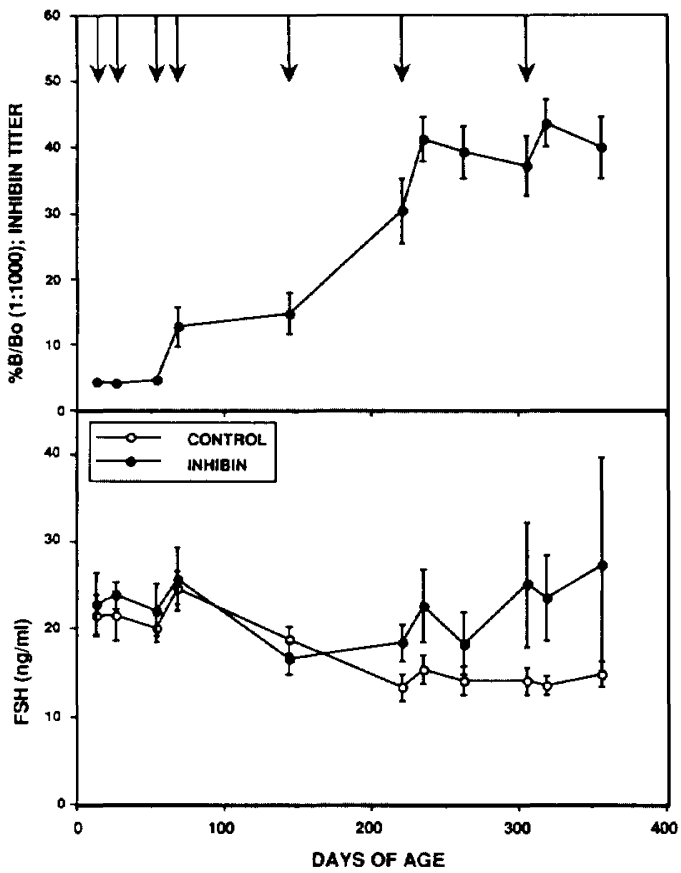

Figure 1. Ontogeny of inhibin [pI $\alpha(1-30)]$ antibody titer in sera of actively immunized bulls (top panel) and serum FSH concentrations for control and immunized bulls during the course of the study (bottom panel). Arrows denote times of first (primary) and secondary (booster) immunizations.

30) synthetic fragment exhibited increased circulating antibodies to radiolabeled pI $\alpha(1-$ 30) after the second booster immunization (Figure 1). Mean specific binding titer reached its maximum $\left(43 \%\right.$ of $B / B_{0}$ in sera diluted 1,000 -fold) $14 \mathrm{~d}$ after the last booster ( $316 \mathrm{~d}$ of age; Figure 1) and fell slightly to $38 \%$ specific binding at the time of slaughter (395 d of age; Table 1). Maximum binding of tracer to antibody by this method was $92 \%$.

Hormonal Changes in Control and Immunized Bulls. Serum FSH concentrations in immunized bulls paralleled those in controls through $140 \mathrm{~d}$ of age (Figure 1). Thereafter, values in controls remained low and stable, whereas those for immunized bulls increased slightly. As a result, FSH levels were higher $(P$ $<.05$ ) for immunized bulls starting at $218 \mathrm{~d}$ of age.

Serum FSH was elevated $(P<.05)$ in immunized bulls compared with control bulls during the 5-h intensive bleed (Figure 2). Serum FSH tended to be lower during the intensive blood sampling than during the ontogeny study (Figure 1), perhaps due to the blood sampling procedure (cannula vs venipuncture). Secretory episodes or periods of elevated FSH were not observed before GnRH administration. Serum LH levels were static in immunized bulls during the 5 -h intensive bleed, but three control bulls each exhibited an LH secretory episode during this bleed. These secretory episodes caused a temporary increase in mean circulating $\mathrm{LH}$ and testosterone levels but were not associated with changes in FSH or inhibin (Figure 2). The 10- $\mathrm{g}$ GnRH challenge administered after $300 \mathrm{~min}$ of sampling caused a marked increase in both serum LH and FSH with mean peak amplitude (45 $\mathrm{ng} \mathrm{LH/ml}$ and $44 \mathrm{ng} \mathrm{FSH} / \mathrm{ml}$ ) and area under response curve (128 $\mathrm{ng} \mathrm{LH/ml}$ and 194 ng $\mathrm{FSH} / \mathrm{ml})$ generally being higher $(P<.10)$ for pI $\alpha(1-30)$-immunized bulls than for control bulls (34 $\mathrm{ng} \mathrm{LH/ml} \mathrm{and} 24 \mathrm{ng} \mathrm{FSH/ml;} 105 \mathrm{ng}$ $\mathrm{LH} / \mathrm{ml}$ and $99 \mathrm{ng} \mathrm{FSH} / \mathrm{ml}$ ). Serum inhibin concentrations in control bulls fluctuated during the 5-h intensive bleed and were not affected for $2 \mathrm{~h}$ following $\mathrm{GnRH}$-induced release of both LH and FSH (Figure 2).

Pituitary Gonadotropins. Neither weight of anterior pituitary nor content or concentration of LH and FSH within anterior pituitary was affected by treatment (Table 1). Although mean pituitary FSH tended to be higher and mean pituitary LH tended to be lower in immunized bulls, their values were not significantly correlated and pituitary FSH/LH ratios for control $(.60 \pm .08)$ and immunized bulls (.75 \pm .14$)$ were not different $(P>.10)$.

At the time of slaughter, inhibin antibody titers remained high, and mean serum FSH concentrations were nearly twice as high in immunized as in control bulls (Table 1). Although serum FSH in immunized bulls was quite variable, mean FSH level tended to be different from controls $(P<.10)$. Within immunized bulls, serum antibody titer was positively correlated with both serum FSH ( $\mathrm{r}=$ $.81, P<.05)$ and pituitary FSH content $(\mathrm{r}=$ $.84, P<.05)$, suggesting that the success of inhibin immunoneutralization affected pituitary FSH synthesis and(or) release.

Testicular Sperm (Spermatid) Production. Body weights at slaughter were similar $(P>$ .10) for control and immunized bulls, as were weights of testes, epididymides and seminal vesicles (Table 2 ). Total daily sperm production (TDSP), as determined by counting homogenization-resistant testicular sperm/sper- 
TABLE 1. SERUM ANTIBODY TITERS, SERUM CONCENTRATIONS OF FSH AND INHIBIN AT SLAUGHTER AND PITUITARY LH AND FSH CONTENT OF CONTROL AND INHIBIN-IMMUNIZED BULLS ${ }^{\mathrm{a}}$

\begin{tabular}{|c|c|c|c|c|c|c|c|c|c|}
\hline \multirow[b]{2}{*}{ Treatment } & \multirow[b]{2}{*}{$\mathbf{N}$} & \multirow{2}{*}{$\begin{array}{l}\text { Titer } \\
\mathbf{B} / \mathbf{B}_{0}{ }^{6}\end{array}$} & \multirow{2}{*}{$\begin{array}{l}\mathrm{FSH}, \\
\mathrm{ng} / \mathrm{ml}\end{array}$} & \multirow{2}{*}{$\begin{array}{l}\text { Inhibin, } \\
\text { fmol/ml }\end{array}$} & \multicolumn{5}{|c|}{ Anterior pituitary } \\
\hline & & & & & Wt, mg & $\mathrm{LH}, \mathrm{mg}$ & $\mathrm{LH}, \mathrm{mg} / \mathrm{g}$ & FSH, mg & $\mathrm{FSH}, \mathrm{mg} / \mathrm{g}$ \\
\hline Control & 5 & $<.5$ & $\begin{array}{l}13.5 \\
\pm 1.1\end{array}$ & $\begin{array}{r}113.4 \\
\pm 19.9\end{array}$ & $\begin{array}{r}668 \\
\pm 68\end{array}$ & $\begin{array}{l}3.16 \\
\pm .27\end{array}$ & $\begin{array}{r}4.77 \\
\pm .29\end{array}$ & $\begin{array}{r}1.83 \\
\pm .17\end{array}$ & $\begin{array}{r}2.89 \\
\pm .39\end{array}$ \\
\hline Anti-inhibin & 6 & $\begin{array}{l}38 \\
\pm 6\end{array}$ & $\begin{array}{l}23.5^{\mathrm{c}} \\
\pm 4.0\end{array}$ & $\mathrm{ND}^{\mathrm{d}}$ & $\begin{array}{r}610 \\
+26\end{array}$ & $\begin{array}{r}2.86 \\
\pm .18\end{array}$ & $\begin{array}{l}4.72 \\
\pm .31\end{array}$ & $\begin{array}{r}2.10 \\
\pm .38\end{array}$ & $\begin{array}{r}3.45 \\
\pm .64\end{array}$ \\
\hline
\end{tabular}

${ }^{a}$ Values are means \pm SE.

${ }^{b}$ Percentage specific binding of ${ }^{125} \mathrm{I}-\mathrm{pI} \alpha(1-30)$ to serum diluted 1,000 -fold. Binding of ${ }^{125} \mathrm{I}$-pI $\alpha(1-30)$ to rete testis fluid of both control and inhibin-immunized bulls was nondetectable.

${ }^{c}$ Except for serum FSH $(P<.10)$, treatment means did not differ $(P>.10)$ for any of the above traits.

$\mathrm{d}_{\mathrm{ND}}$, not determined.

matid and dividing by a 5.32-d time divisor, suggested that sperm production was greater by immunized bulls; however, sperm numbers were only marginally different $(P<.10)$ when expressed as homogenization-resistant sperm per gram of testicular parenchyma. The lack of significance for TDSP may reflect the absence of an immunization effect or simply the lack of power and sensitivity to detect the true effect. Testes weights within immunized bulls were negatively correlated with both serum FSH ( $r$ $=-.73, P<.10)$ and serum antibody titer $(r=$ $-.93, P<.01)$. Despite high titers to $\mathrm{pI} \alpha(1-30)$ in the peripheral circulation, $\mathrm{pI} \alpha(1-30)$ binding was not present $(<2.5 \%)$ in rete testis fluid of immunized bulls. Hot carcass weights, as well as USDA carcass quality grades and yield scores, were not affected by treatment (data not shown).

\section{Dlscussion}

Immunoassay data reported herein confirm two other reports (Miyamoto et al., 1989; MacDonald et al., 1990) showing that young bulls secrete and circulate significant quantities of inhibin in peripheral blood. Immunolocalization studies in rats (Bardin et al., 1989) and rams (Veeramachaneni et al., 1989) have shown that inhibin alpha reactivity is most prominent in the seminiferous tubules of the testes, with the most intense staining localized within Sertoli cells. This specific cellular localization was confirmed in, but not restricted to, primary Sertoli cell-enriched cultures (Bardin et al., 1989). This finding coupled with FSH suppressing activity (Setchell and Jacks, 1974) and inhibin alpha immunoreactivity (Veeramachaneni et al., 1989) in ram rete testis fluid strongly suggests that the seminiferous tubules and fluids of the excurrent duct system are the primary source of circulating inhibin in males. In accord with the initial objectives, binding titers to $\mathrm{pI} \alpha(1-$ 30) were achieved in immunized beef bulls; however, antibodies were not observed in rete testis fluid. In view of the importance of the blood-testis barrier to spermatogenesis and sperm transport, the absence of $\mathrm{pI} \alpha(1-30)$

TABLE 2. WEIGHTS OF TESTES, EPIDIDYMIDES AND SEMINAL VESICLES AND TOTAL DAILY SPERM PRODUCTION (TDSP) OF CONTROL AND INHIBIN-IMMUNIZED BULLS ${ }^{a}$

\begin{tabular}{|c|c|c|c|c|c|c|c|}
\hline Treatment & $\mathrm{N}$ & $\begin{array}{l}\text { Body } \\
\text { wt,kg }\end{array}$ & $\begin{array}{l}\text { Testes } \\
\mathbf{w t ,} \mathbf{g}\end{array}$ & $\begin{array}{l}\text { TDSP, } \\
\times 10^{9}\end{array}$ & $\begin{array}{l}\text { Sperm/g } \\
\text { testis, } \\
\times 10^{6}\end{array}$ & $\begin{array}{l}\text { Epididymides } \\
\text { wt, } g\end{array}$ & $\begin{array}{l}\text { S. vesicles } \\
\text { wt, } \mathbf{g}\end{array}$ \\
\hline Control & 5 & $\begin{array}{l}453.6 \\
\pm 27.8\end{array}$ & $\begin{array}{l}484.2 \\
\pm 44.1\end{array}$ & $\begin{array}{r}3.74 \\
\pm .56\end{array}$ & $\begin{array}{l}44.9 \\
\pm 4.2\end{array}$ & $\begin{array}{r}41.6 \\
\pm 3.3\end{array}$ & $\begin{array}{r}61.4 \\
\pm 6.8\end{array}$ \\
\hline Anti-inhibin & 6 & $\begin{array}{l}467.3 \\
\pm 16.1\end{array}$ & $\begin{array}{l}521.8 \\
\pm 60.2 \\
\end{array}$ & $\begin{array}{l}5.52 \\
\pm .98\end{array}$ & $\begin{array}{l}59.6^{b} \\
\pm 5.5\end{array}$ & $\begin{array}{l}46.4 \\
\pm 4.6\end{array}$ & $\begin{array}{r}61.3 \\
\pm 3.1\end{array}$ \\
\hline
\end{tabular}

${ }^{\mathrm{a}}$ Values are means $\pm \mathrm{SE}$.

${ }^{b}$ Except for sperm/g testis $(P<.10)$, treatment means did not differ $(P>.10)$ for any of the above traits. 
antibodies in rete testis fluid is not surprising. The abundance of these antibodies in follicular fluid of immunized cows (Schanbacher, 1989), but not in rete testis fluid of immunized bulls,

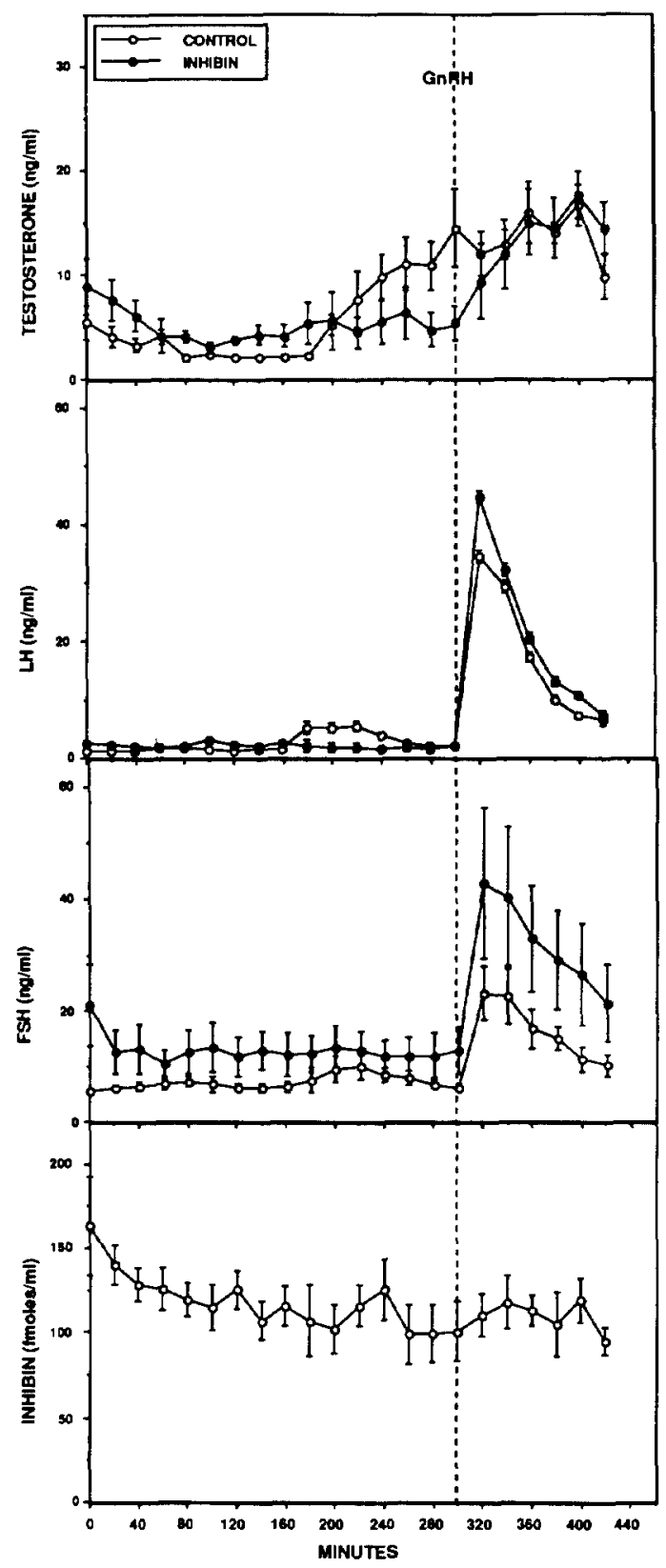

Figure 2. Serum concentrations of testosterone, LH, FSH and inhibin in control and inhibin [pI $\alpha(1-30)]$ immunized bulls during a 7-h intensive bleed at $312 \mathrm{~d}$ of age. Gonadotropin-releasing hormone challenge $(10 \mu \mathrm{g})$ was given after 300 min of sampling. Inhibin concentrations were not determined in sera of immunized bulls. illustrates a potential sex difference in mode of action of inhibin immunization effects on male and female gametogenesis.

Unlike its prominent role during cyclicity and the development of ovarian follicles in females, inhibin appears to play an important role in the feedback regulation of FSH during the prepubertal period in males. During the prepubertal period, Sertoli cell numbers are determined and adjustments in the FSH/inhibin feedback system take place. The contention that FSH is regulated by inhibin is supported by the positive correlation observed in this study between inhibin antibody titer and FSH in both pituitary and serum. Although testes weight and total daily sperm production of bulls actively immunized against the inhibin alpha subunit pI $\alpha(1-30)$ were not significantly increased over that of control bulls, immunized bulls tended to have increased peripheral FSH levels and testicular sperm density. If these results were dependent on prepubertal manipulation of the FSH/inhibin endocrine axis, as suggested by similar studies involving passive immunoneutralization of endogenous inhibin in prepubertal male rats (Culler and NegroVilar, 1988), it was fortuitous that this active immunization study began in beef bulls at an early age.

The $\mathrm{pI} \alpha(1-30)$ fragment of inhibin was used as antigen in this study because of its apparent antigenicity and specificity toward the inhibin molecule (Schanbacher, 1988a). Immunization against one of the inhibin beta subunits was not attempted because of its lack of suitability as RIA antigen, potential cross-reactivity with activin and apparent inability to serve as a profertility antigen in females (B. D. Schanbacher, unpublished data). Although both inhibin alpha and inhibin beta subunits have been identified in ovine testes, activin (a betabeta dimer) has not been isolated from a testicular source (Bardin et al., 1989).

The small, significant change in serum FSH, but not LH, in immunized bulls was not apparent for content or concentrations of FSH in anterior pituitaries. Although the pituitary FSH/LH ratio was slightly higher for immunized than for control bulls, this provided little insight into the role of endogenous inhibin on pituitary FSH synthesis and release. In contrast, heifers immunized against the same $\operatorname{pI} \alpha(1-30)$ antigen had increased pituitary FSH content $(27 \%)$ but unchanged serum FSH levels and no change in the distribution of 
pituitary FSH isohormones compared with nonimmunized controls (Schanbacher, 1989).

In summary, active immunization of beef bulls against the inhibin alpha subunit pI $\alpha(1-$ 30) resulted in circulating antibody titers, increased serum FSH levels and increased testicular sperm density. Although TDSP approached significance $(P \sim .10)$, immunization did not affect growth rates of bulls or weights of testes, epididymides and seminal vesicles. Serum inhibin levels were reasonably static throughout the day in beef bulls, as were FSH levels; they were not acutely affected by GnRH-induced changes in serum LH and FSH.

\section{Impilcations}

Inhibin is a physiologically important hormone of testicular origin in beef bulls; its secretion is not affected acutely by changes in gonadotropin secretion. Because body weight gain, testosterone secretion and weights of testes, epididymides and seminal vesicles were not adversely affected by inhibin vaccination, additional immunization studies are warranted to determine the functional relationships between inhibin immunoneutralization, secretion of follicle-stimulating hormone and spermatogenesis in beef bulls destined for natural service or artificial insemination use.

\section{Literature Clted}

Amann, R. P., J. F. Kavanaugh, L. C. Griel, Jr. and J. K. Voglmayr. 1974. Sperm production of Holstein bulls determined from testicular spermatid reserves, after cannulation of rete testis or vas deferens, and by daily ejaculation. J. Dairy Sci. 57:93.

Bardin, C. W., P. L. Morris, C. Shaha, Z. M. Feng, V. Rossi, J. Vaughan, W. W. Vale, J. Voglmayr and C.L.C. Chen. 1989. Inhibin structure and function in the testis. Ann. NY Acad. Sci. 564:10.

Culler, M. D. and A. Negro-Vilar. 1988. Passive immunoneutralization of endogenous inhibin: Sexrelated differences in the role of inhibin during development. Mol. Cell. Endocr. 58:263.

Keel, B. A. and B. D. Schanbacher. 1987. Charge microheterogeneity of ovine follicle stimulating hormone in rams and steroid-treated wethers. Biol. Reprod. 37:786.

Keel, B. A., B. D. Schanbacher and H. E. Grotjan, Jr. 1987. Ovine luteinizing hormone. I. Effects of castration and steroid administration on the charge micro heterogeneity of pituitary LH. Biol. Reprod. 36:1102.
Krystek, Jr., S. R., J. A. Dias, L. E. Reichert, Jr. and T. T. Andersen. 1985. Prediction of antigenic sites in follicle-stimulating hormones: Difference profiles enhance antigenicity prediction methods. Endocrinology 117:1125.

Ling, N., S. Y. Ying, N. Ueno, F. Esch, L. Denoroy and R. Guillemin. 1985. Isolation and partial characterization of a $M_{S} 32,000$ protein with inhibin activity from porcine follicular fluid. Proc. Natl. Acad. Sci. USA 82: 7217.

MacDonald, R. D., D. R. Deaver and B. D. Schanbacher. 1990. Prepubertal changes in plasma FSH and inhibin in Holstein bulls calves: Responses to castration and(or) estradiol. J. Anim. Sci. (In press).

McCullagh, D. R. 1932. Dual endocrine activity of testes. Science 76:19.

Miyamoto, A., M. Umezu, S. Ishii, T. Furusawa, J. Masaki, Y. Hasegawa and M. Ohta. 1989. Serum inhibin FSH, LH and testosterone leveis and testicular inhibin content in beef bulls from birth to puberty. Anim. Reprod. Sci. 20:165.

Miyamoto, K., Y. Hasegawa, M. Fukada, M. Nomura, M. Igarashi, K. Kangawa and H. Matsuo. 1985. Isolation of porcine follicular fluid inhibin of $32 \mathrm{~K}$ daltons. Biochem. Biophys. Res. Commun. 129:396.

Robertson, D. M., L. M. Fouldo, L. Leversha, F. J. Morgan, M.T.W. Hearn, H. G. Burger, R.E.H. Wettenhall and D. M. de Kretser. 1985. Isolation of inhibin from bovine follicular fluid. Biochem. Biophys. Res. Commun. 126:220.

SAS. 1985. SAS User's Guide: Statistics. SAS Inst., Inc., Cary, NC.

Schanbacher, B. D. 1988a. Radioimmunoassay of inhibin: Serum responses to unilateral and bilateral orchidectomy. Endocrinology 123:2323.

Schanbacher, B. D. 1988b. Increased ovulatory response of Suffolk ewes vaccinated against a synthetic fragment of porcine inhibin. Biol. Reprod. 38:62 (Abstr.).

Schanbacher, B. D. 1989. Ovulation response and pituitary FSH charge microheterogeneity in beef heifers vaccinated against synthetic porcine inhibin alpha. J. Anim. Sci. 67(Suppl. 1):361 (Abstr.).

Schanbacher, B. D. and M. J. D'Occhio. 1982. Validation of a direct radioimmunoassay for testosterone in unextracted serum from five species: Application to study of the hypothalamic-pituitary-gonadal axis in males. J. Androl. 3:45.

Schanbacher, B. D., M. J. D'Occhio and J. E. Kinder. 1982. Initiation of spermatogenesis and testicular growth in oestradiol-17 $\beta$-implanted bull calves with pulsatile infusion of luteinizing hormone releasing hormone. J. Endocrinol. 93:183.

Schanbacher, B. D. and S. E. Echternkamp. 1978. Testicular steroid secretion in response to GnRH-mediated LH and FSH release in bulls. J. Anim. Sci. 47:514.

Setchell, B.P. and F. Jacks. 1974. Inhibin-like activity in rete testis fluid. J. Endocrinol. 62:675.

Veeramachaneni, D.N.R., B. D. Schanbacher and R. P. Amann. 1989. Immunolocalization and concentrations of inhibin- $\alpha$ in the ovine testis and excurrent duct system. Biol. Reprod. 41:499. 